The Classical Quarterly 70.2 884-890 (C) The Author(s), 2021. Published by Cambridge University Press on behalf of The Classical Association. This is an Open Access article, distributed under the terms of the Creative Commons Attribution-NonCommercial-ShareAlike licence (http:/creativecommons.org/licenses/ by-nc-sa/4.0/), which permits non-commercial re-use, distribution, and reproduction in any medium, provided the same Creative Commons licence is included and the original work is properly cited. The written permission of Cambridge University Press must be obtained for commercial re-use.

\title{
BEES AND VULTURES: EGYPTIAN HIEROGLYPHS IN AMMIANUS MARCELLINUS*
}

In his Res Gestae, the historian Ammianus Marcellinus describes the Egyptian city of Thebes and the obelisks that can be found there. There is an unusual passage in which he describes hieroglyphic writings. He goes on to show, through two examples, how hieroglyphs might seem bizarre, but in fact contain their own logic which can be explained (Amm. Marc. 17.4.10-11, translation mine):

non enim ut nunc litterarum numerus praestitutus et facilis exprimit quicquid humana mens concipere potest, ita prisci quoque scriptitarunt Aegyptii, sed singulae litterae singulis nominibus seruiebant et uerbis; non numquam significabant integros sensus. cuius rei scientiam his inseram duobus exemplis. per uulturem naturae uocabulum pandunt, quia mares nullos posse inter has alites inueniri rationes memorant physicae, perque speciem apis mella conficientis indicant regem moderatori cum iucunditate aculeos quoque innasci debere his signis ostendentes. et similia plurima.

For the ancient Egyptians did not write as nowadays, when a prescribed and easy series of letters expresses whatever the human mind can imagine; but individual characters served as individual nouns and verbs; and sometimes they signified whole ideas. I will show the knowledge of this with these two examples. They represent the word for 'nature' by a vulture, because no males can be found among these birds, as natural history records; and by the figure of the bee making honey they indicate 'a king', showing by these signs that in a ruler stings also ought to arise from sweetness. And there are many similar instances.

As it stands, the rationale in this passage seems strange. Most scholarship on this chapter of Ammianus has focussed on other aspects, such as Hermapion ${ }^{1}$ and the Greek translation of the obelisk Ammianus provides. ${ }^{2}$ In his commentary, de Jonge assumes that Ammianus was 'misled by the fairy tales' about hieroglyphic script, and suggests that Ammianus' explanation does not tie in with the depth of meanings in Hermapion's translation. ${ }^{3}$ However, Ammianus' explanation of the hieroglyphs is worthy of closer examination, as it reveals more understanding than he is usually given credit for.

Ammianus' second example is the more straightforward of the two to understand, as the phrase is extremely common in hieroglyphic inscriptions. Bill Thayer, on the Lacus

* With thanks to Richard Flower for drawing this passage to my attention, and to my Middle Egyptian teacher, Sian Thomas.

${ }^{1}$ A. Benaissa, 'Ammianus Marcellinus Res Gestae 17.4.17 and the translator of the obelisk in

Rome's Circus Maximus', ZPE 186 (2013), 114-18.

${ }^{2}$ For Hermapion, see $B N J 658$ (S. Gambetti).

${ }^{3}$ P. De Jonge, Philological and Historical Commentary on Ammianus Marcellinus XVII. (Groningen, 1977), 84. 
Curtius website, ${ }^{4}$ has shown that, when Ammianus describes speciem apis mella conficientis ('the figure of a bee making honey') he is probably thinking of this ubiquitous royal title:

\section{格 $n$ swt-bity}

As Thayer comments, 'the insect is indeed a bee, and appears to be doing something to a plant; depending on your eyesight-mine's not that good-you might say she's making honey, but as it turns out, she isn't'. Equally, the two semicircular signs appearing below the bee and the plant could be mistaken for drops of honey inside a honeycomb. However, as Egyptian hieroglyphs are frequently phonetic rather than purely symbolic, these shapes are actually the sign representing the letter ' $t$ '. Middle Egyptian hieroglyphs have been classified by Alan Gardner, ${ }^{5}$ and in his classification this sign is listed as sign X1: ๑. The complete phrase, characteristically used in inscriptions, is a contraction of two much fuller terms for the king, each with multiple meanings:

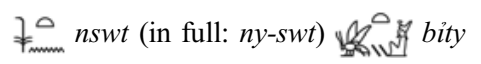

The orthography here is quite complex. The plant in the first of these lexemes is the sedge plant (Gardiner, M23: ¥), which has the phonetic value $s w$. A variant sign is the flowering sedge (Gardiner, M26: ł), which has the phonetic value $\breve{S} m$ r. Both of these signs can be used to write distinct words relating to Upper (southern) Egypt. ${ }^{6}$ The bee in the second lexeme (Gardiner, L2: has the phonetic value bi. This sign can be used to write words relating to Lower (northern) Egypt. ${ }^{7}$ The two signs as a royal title have sometimes been understood as signifying the whole of Egypt, linked to the idea of the 'two lands'. ${ }^{8}$ However, the two terms also signify different aspects of the king. The word nswt (a very common abbreviated form still includes the ideogram M23: ¥) is a general word for king, indicating the king's role on earth acting among humans. The word bity is a relatively rarefied and ritualistic term for 'ancestral king', identifying the king as 'the current incarnation of a line of royal ancestors'. 9 The title thus carries a dual meaning, potentially signifying time and place, and is usually translated today as 'Dual King'. Ammianus picks up on the idea of a double meaning (sweetness and harshness), accurately linking that to the image of the bee (which may be both king of Lower Egypt and ancestral king). Ammianus figures the doubleness of the meaning differently, lacking detailed knowledge of the orthography and language. Perhaps ironically, the word for honey III $^{10}$ is related, containing two of the signs from the word bity. It is thus very likely that Ammianus' source was not entirely ignorant of the language.

\footnotetext{
${ }^{4}$ B. Thayer, http://penelope.uchicago.edu/Thayer/E/Roman/Texts/Ammian/17*.html\#note:Ammian on_pictographic_character_of_hieroglyphics (consulted 3 December 2019).

${ }_{5}^{5}$ A. Gardiner, Egyptian Grammar (Oxford, 1957).

${ }^{6}$ See Gardiner (n. 5), 139; R. Faulkner, A Concise Dictionary of Middle Egyptian (Oxford, 1962), 139; J. Allen, Middle Egyptian: An Introduction to the Language and Culture of Hieroglyphs (Cambridge, 2014 $\left.{ }^{3}\right), 485$.

${ }^{7}$ Faulkner (n. 6), 79.

${ }^{8}$ T. Barnes, Ammianus Marcellinus and the Representation of Historical Reality (Ithaca, 1998), 9 and 127.

${ }^{9}$ Allen (n. 6), 83.

${ }^{10}$ Gardiner (n. 5), 477.
} 
Ammianus' other example, the vulture, is more complex to unravel. The most common hieroglyphic vulture is Gardiner's sign G1 (A), a standing bird with a sharp beak. This is a single consonant sign for an alef (3) which is used in a great number of words. Thayer assumes that there must have been a word for nature spelled using this sign. However, this is not the only vulture in the Egyptian sign list-there is another vulture, Gardiner's sign G14 (\$), a standing bird with a hunched back and curved neck. This sign is a phonogram $m t, m w t$, miwt, and also a determinative in $n r t$ (vulture) and words with root $n r$. Its most common use is in the word $m w t$ (mother). ${ }^{11}$ Herman te Velde has demonstrated how this sign consistently refers to femininity and motherhood. ${ }^{12}$ A simple variant of this sign, a vulture with a flail (Gardiner, G15: is used to write the name of the goddess Mut, the mother goddess of Thebes. This sign (G14 or its variant G15) is the vulture which Ammianus (or his source) seems to be referring to.

The explanation lies in the rather obscure reason he gives for this, quia mares nullos posse inter has alites inueniri rationes memorant physicae ('because no males can be found among these birds, as natural history records'). Here, Ammianus repeats a theory which seems to have been widespread in antiquity since Aristotle (Hist. an. 8[9].615a), and perhaps arose in Egypt, that male vultures did not exist and female vultures procreated with the north wind instead (Ael. NA 2.46; Plut. Mor. 286C). ${ }^{13}$ This slightly bizarre idea seems to have been common regarding animals where procreation could not be observed (fish and insects, for example) and, in the case of the vulture, because male and female birds were indistinguishable. Such an idea is suggested in the demotic version of the Myth of the Solar Eye preserved in the second-century C.E. P.Leiden I 384, IX 7-8, where the vulture describes its species as one of which no males exist. ${ }^{14}$ Erich and Ute Winter suggest further indigenous Egyptian links beyond this papyrus, potentially taking the germ of the idea back to the ninth century B.C.E. ${ }^{15}$ Another late antique text, purporting to be the work of Horapollo Nilous and claiming to elucidate hieroglyphs, contains an extended section on vultures. This text ${ }^{16}$ gives a range of meanings for the sign of the vulture, beginning the section with an overview:

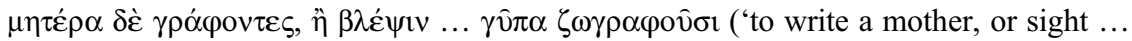
they draw a vulture', 1.11). The author treats all these meanings one after another in the chapter, making no distinction in orthography. He explains that the vulture indicates a

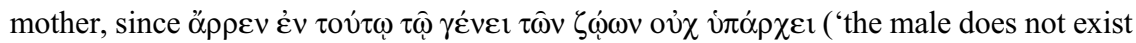
in this species of animal', 1.11), a similar explanation to the one Ammianus provides. The author describes the procreative habits of the vulture in some detail: ö $\tau \alpha v$

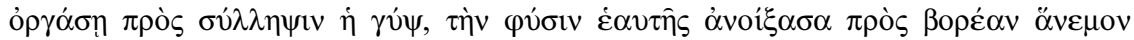
('whenever the vulture desires conception, it lays open its procreative organs to the north wind', 1.11). However, a few lines later, he also states that a vulture indicates

\footnotetext{
11 Allen (n. 6), 480.

${ }^{12}$ H. te Velde, 'The Goddess Mut and the vulture', in S.H. D'Auria (ed.), Servant of Mut: Studies in Honour of Richard A. Fazzini (Leiden, 2007), 242-5, at 244.

${ }^{13}$ C. Zirkle, 'Animals impregnated by the wind', Isis 25 (1936), 95-130, at 105-7.

14 See W. Spiegelberg, Der ägyptische Mythus vom Sonnenauge (Strassburg, 1917), 28-9; M. Smith, 'Review of F. de Cenival, Le mythe de l'oeil du soleil (Demotische Studien 9) (Sommerhausen, 1988)', BO 49 (1992), 80-95, at 93.

${ }^{15}$ E. Winter and U. Winter, 'Von der Ununterscheidbarkeit der Geschlechter: Der Geier im Flug durch die Jahrtausende', in I. Slawinski and J.P. Strelka (edd.), Viribus Unitis (Bern, 1996), 52337 , at 530 .

${ }^{16}$ F. Sbordone, Hori Apollinis Hieroglyphica (Hildesheim, 1940; repr. 2002).
} 


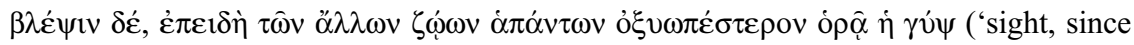
of all other animals the vulture sees more keenly', 1.11). Here, it is possible that the author (or his source) conflates Gardiner's G1 vulture (A), a common simple phonetic sign, which is used very frequently, including in writing the word to see ( $m_{33}$ ), with Gardiner's G14 vulture (N), used in mother. Alternatively, the author may be recalling an Egyptian fable of Sight and Hearing, in which the two senses are personified by two vultures. ${ }^{17}$ Horapollo is too late to have been a source for Ammianus, but the two texts may share a common source. The amalgamation of the different vultures in Horapollo may help to explain the lack of qualifying detail in Ammianus.

Although we cannot know what Ammianus' source was for the hieroglyphic information, it is possible that it was either the work of the first-century Egyptian priest Chaeremon, or that it was derived from Chaeremon or a similar type of text. Pieter Willem van der Horst includes paragraph 17.4.11 of Ammianus as a doubtful fragment of Chaeremon's lost text ${ }^{18}$ on the grounds that it resembles some of the information in a fragment of Chaeremon preserved in Tzetzes, Exegesis in Iliadem 1.97.19 Tzetzes

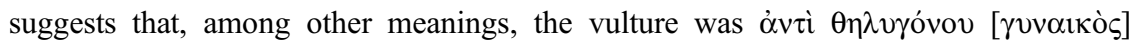

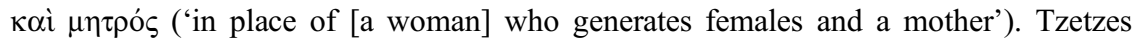
does not give any allegorical or etymological explanations, but he simply lists the various possible meanings for the sign. His list of meanings ranges across classical and Ptolemaic uses, but all those meanings are confined to the G14 vulture, unlike Horapollo's text. However, Tzetzes' unusual word $\theta \eta \lambda v$ yóvos provides a clue for how we might interpret Ammianus' natura. The word natura has a considerably wide range of meanings, beyond the English word 'nature'. The $O L D$ gives fifteen groups of meanings, including innate character $(1,3,11)$, natural order $(2,4,5)$, course of events (6), creation (7), characteristics $(8,9,10)$, features (8b), endowments (12), appearance (13), order of being (14) and organs of generation (15).20 The last of

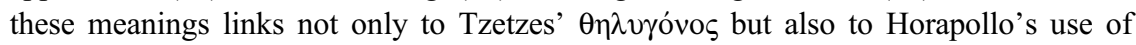
the word $\varphi v i \sigma i \varsigma$ in his description of the procreative habits of the female vulture, and is the meaning van der Horst suggests for this passage as a fragment of Chaeremon. ${ }^{21}$ If Ammianus' source was Greek, which is very likely, he would have been translating one of these words into Latin, and he therefore uses the word natura in this very specific sense. In fact, the Egyptian word for womb or uterus is written using the same vulture, in a compound word which literally means 'mother of humanity': direct or indirect) would have been aware of this use of the vulture hieroglyph, prompting this specific meaning in Greek words such as $\theta \eta \lambda v \gamma o ́ v o \varsigma$ and $\varphi v i \sigma 1 \varsigma$.

The word natura has many meanings in Latin, and this definition is perhaps the least common, as reflected in its position as the final meaning listed in the $O L D$ and as the

${ }^{17}$ W.J. Tait, 'The fable of sight and hearing in the demotic Kufi text', Acta Orientalia (Societates Orientales Danica, Norvegica, Svecica) 37 (1976), 27-44, at 28, 38 and 41.

18 P.W. van der Horst, Chaeremon, Egyptian Priest and Stoic Philosopher: The Fragments Collected and Translated with Explanatory Notes (Leiden, 1987²), 45.

${ }^{19}$ Van der Horst (n. 18), 73.

${ }^{20}$ P.G.W. Glare (ed.), Oxford Latin Dictionary (Oxford, 2012²), 1274-5.

21 Van der Horst (n. 18), 73.

22 A. Erman and H. Grapow (edd.), Wörterbuch der ägyptischen Sprache, vol. 2 (Berlin and Leipzig, 1928), 54. 
penultimate and shortest section on the word in the TLL (9.1.188.19-66). natura is used in this sense by Cicero in Diu. 1.36 (of a mule) and 2.145 (of a woman's womb), and Pease notes this precise meaning at both instances in his commentary. ${ }^{23}$ Cicero also uses the word in Nat. D. 2.128 (about creatures in general) and 3.56 (about an image of Mercury with an erection). To this latter, Pease gives an extensive comment, noting that the word can apply to both male and female organs. ${ }^{24}$

Ammianus' frequent references to and borrowings from Cicero suggest that he had an extensive knowledge of a great deal of Cicero's writings, including those which are no longer extant. ${ }^{25} \mathrm{He}$ could thus have been familiar with this shade of meaning for the word natura from Cicero's work, and Owens has demonstrated how Ammianus borrowed from both books of De diuinatione, ${ }^{26}$ and also showed familiarity with all three books of De natura deorum. ${ }^{27}$ In his extensive commentary on Ammianus, de Jonge $^{28}$ observes that the historian's use of the word ratio in his description of the vulture echoes a meaning frequently found in Cicero (theory, science). He suggests that when Ammianus writes rationes physicae ('natural history') he is probably echoing Cicero's phrase physicae rationis in Nat. D. 2.21. However, de Jonge argues that natura should be read as the idea of Nature from a Neoplatonic point of view. ${ }^{29} \mathrm{He}$ emphasizes this by reading the term uocabulum as 'concept', rather than 'word', ${ }^{30}$ thus stressing the allegorical aspect of the interpretation.

The hieroglyph of the bee is described by both Tzetzes and the text of Horapollo.

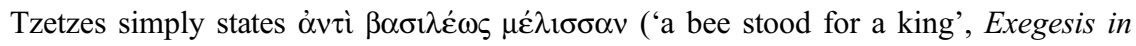
Iliadem 1.97), and then moves on to describe what a beetle stood for. The text of Horapollo, on the other hand, reads the bee as standing for $\lambda \alpha$ òv $\pi \rho \grave{\varsigma} \beta \beta \sigma \sigma \lambda \lambda \dot{\varepsilon} \alpha$ $\pi \varepsilon \imath \theta$ ńviov ('people obeying a king', 1.62), rather than for the king himself. The author draws a link between the behaviour of the people and the bees, since only bees have a

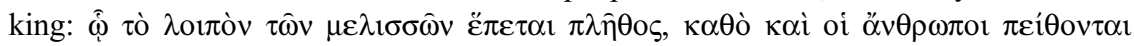
$\beta \alpha \sigma i \lambda \varepsilon \hat{i}$ ('which the rest of the bees follow as a mass, as people obey a king', 1.62). Sbordone acknowledges the inaccuracy of the bee indicating people rather than king and suggests that this allows the author to digress on the idea of bees obeying their king, on which there are both Latin and Greek accounts. ${ }^{31}$ However, the text of

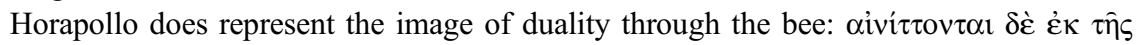

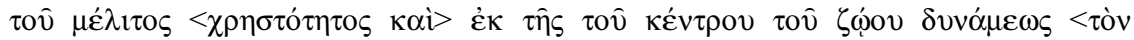

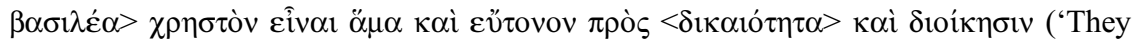
speak in riddles of the goodness of honey and of the power of the animal's sting that the king is both good and strong in justice and governance', 1.62). This is a rather garbled version of the same point which Ammianus states about the link between a bee and a king, though appearing somewhat uneasily after the people, rather than

23 A.S. Pease, M. Tulli Ciceronis De Divinatione, 2 vols. (Urbana, 1920-3), 2.154 and 2.576.

24 A.S. Pease, M. Tulli Ciceronis De Natura Deorum: Libri Secundus et Tertius (Cambridge, MA, 1958), 1108.

${ }^{25}$ F.W. Jenkins, 'Ammianus Marcellinus's knowledge and use of Republican Latin literature' (Ph.D. Thesis, Urbana University, 1985), 91.

${ }^{26}$ E.E.L. Owens, 'Phraseological parallels and borrowings in Ammianus Marcellinus from earlier Latin authors' (Ph.D. Thesis, Birkbeck College, London, 1958), 123-5.

27 Owens (n. 26), 130-13.

28 De Jonge (n. 3), 91.

${ }^{29}$ De Jonge (n. 3), 91.

${ }^{30}$ De Jonge (n. 3), 90.

31 Sbordone (n. 16), 126. 
their king, have been defined by the bee. Although the precise examples Ammianus has selected appear in different passages of Horapollo, both of them appear in the same paragraph in Tzetzes, who also lists the bee directly after the vulture. Ammianus has selected only one meaning for each sign in comparison with the range of meanings Tzetzes lists for the vulture, and he has kept explanations about both animals. However, the juxtaposition of the vulture and the bee in Ammianus and Tzetzes strongly points to a common source, one which the author of Horapollo's text very probably also used.

Ammianus thus has taken his source (perhaps Chaeremon or an intermediary text) and chosen to give two examples of hieroglyphic meanings. Ammianus is not exactly right about the meanings of either hieroglyph, but there is some truth in what he says about each, though it is slightly distorted. By Late Antiquity, Egyptian priests and scribes had vastly increased the number and uses of hieroglyphic signs since the earlier period, and Ptolemaic inscriptions could use characters in complex and cryptographic ways. Surviving fragments of Egyptian language treatises from the Roman era contain etymologies which did not regard the words in a linguistic sense, but considered their elements in a mythical sense. ${ }^{32}$ The 'definitions' of words found in P.Carlsberg VII (an indigenous Egyptian treatise) sometimes take into account the sounds of the words through alliteration, ${ }^{33}$ but always link them to mythological ideas concerning the gods. They are written in an obscure fashion, and offer multiple interpretations for individual signs. Van der Horst has suggested that, in order to preserve their prestige and knowledge, it is possible that Egyptian priests in this period were themselves often responsible for promoting ideas about the secret meanings and cryptic knowledge contained in the hieroglyphs. ${ }^{34}$ Ammianus echoes this idea when he states that the signs could be used in many different ways, as both words and phrases, which was more true of Ptolemaic hieroglyphs than of classical ones. ${ }^{35}$ In addition, he supports both of his interpretations with the allegorical style of explanation which had already become popular. However, his explanations function in a similar way to spurious etymologies which we see so often in the Roman world, and particularly in Late Antiquity.

Most commonly, ancient etymological explanations start from the sounds of the words. So, for example, Virgil states that bad fumes mean that no birds can fly over Lake Avernus, unde locum Grai dixerunt nomine Aornum ('hence the Greeks call the place by the name Aornus', Aen. 6.242). Virgil plays with the sounds, rather than with just the appearance, of the words Avernus and öopvos (bird-less). On both occasions, Ammianus (or his source) relies on the characteristics of the animals depicted and the visual way in which they are depicted, rather than on the sounds of the words, on which to frame his explanations. MacMullen has demonstrated how fourth-century culture was particularly focussed on the visual, with reference to descriptions of ceremony in Ammianus. ${ }^{36}$ In other contexts, Barnes has observed how Ammianus uses language in a way that evokes a precise visual image. ${ }^{37}$ Swetnam-Burland has

32 E. Iversen, Papyrus Carlsberg No. VII: Fragments of a Hieroglyphic Dictionary (Copenhagen, 1958), 13.

33 Iversen (n. 32), 12.

${ }^{34}$ P.W. van der Horst, 'Hiërogliefen in de ogen van Grieken en Romeinen', Phoenix: Bulletin uitgegeven door het vooraziatisch-Egyptisch Genootschap EX ORIENTE LVX 30 (1984), 44-53, at 52.

${ }^{35}$ F. Gaudard, 'Ptolemaic hieroglyphs', in C. Woods (ed.), Visible Language: Inventions of Writing in the Ancient Middle East and Beyond (Chicago, 2010), 173-5, at 174.

${ }^{36}$ R. MacMullen, 'Some pictures in Ammianus Marcellinus', ABull 46 (1964), 435-56.

37 Barnes (n. 8), 107. 
suggested that a Roman audience would have seen hieroglyphs as conducting meaning on a visual and symbolic level, and that, given the minority of people trained to read the script, most people would have been struck by the visual display. ${ }^{38}$ Such a reading is not so very different to the way in which tourists tend to regard Egyptian inscriptions in museums today. It is, therefore, highly plausible that, when Ammianus looked at the royal title fis nswt-bity on the obelisks in Rome, he interpreted the explanation provided by his source in a similar way to Thayer's description of a bee 'doing something to a plant'. We do not know exactly how Middle Egyptian sounded, because the script does not represent vowel sounds-we cannot be sure how $m w t$ or nswt-bity actually sounded. It is likely that neither Ammianus nor his source knew this either. But he treats the visual explanation in the same way as he would treat a phonetic etymology.

Faculty of Education, University of Cambridge

FRANCES FOSTER fjf20@cam.ac.uk

${ }^{38}$ M. Swetnam-Burnham, Egypt in Italy: Visions of Egypt in Roman Imperial Culture (Cambridge, 2015), 49. 